\title{
THE MEDIA AS BOTH FRIEND AND ENEMY OF THE STATE
}

\author{
Abiodun Fasakin ${ }^{1}$ Olusola Oyero ${ }^{2 *}$, Nelson Okorie ${ }^{3}$, Lanre Amodu ${ }^{4}$ \\ ${ }^{1} \mathrm{Mr}$, Covenant University, NIGERIA, aiminghigher0017@yahoo.com \\ ${ }^{2}$ Ass. Professor, Dr., Covenant University, NIGERIA, olusola.oyero@covenantuniversity.edu.ng \\ ${ }^{3} \mathrm{Dr}$, Covenant University, NIGERIA, lanre.amadu@covenantuniversity.edu.ng \\ ${ }^{4}$ Dr, Covenant University, NIGERIA, nelson.okorie@covenantuniversity.edu.ng \\ ${ }^{*}$ Corresponding author
}

\begin{abstract}
The mass media - radio, television newspaper, magazine and the internet - are very relevant in every society. They are the channels through information and messages are propagated simultaneously to large number of people in different areas. They are agents of socialisation and education as well as development. The mass media surveys the environment for news, analyse issues of people's interest, provide entertainment and also help the propagation of the societal cultural norms and values. However, in spite of the important roles of the media in the society, they as well have their disadvantageous roles in the society. The study evaluated the mass media as both friend and also as enemy of the state. According to this paper, the media act as friend of the state by serving as watchdogs, agents of cultural transmission and agents of political orientation to the people in the society. However, the media act as enemy of the state as they are used as channels for people, especially politicians to throw abusive words at one another, huge contributors to decadence in our society and they aid the spread of violence and hatred through propagation of hate speeches and words that can incite people into violence. The researcher concluded that the media have been both constructive (friend) and destructive (enemy) to the society. The study recommended that the media should keep to their social responsibility functions and adhere to the ethics of the profession in all their operations.
\end{abstract}

Keywords: Watchdog, Cultural transmission, Social responsibility

\section{INTRODUCTION}

For many years, the mass media have been vital tools for information dissemination, education and entertainment to the people. In addition to their numerous functions in the society, the mass media are important partners to the government in national development. Mass media refer to the collection of all media technologies that are used to send information to a large and heterogeneous audience.

According to Dominick (2009), the mass media are the channels through which a message travels from the source to the receiver through an institution that uses these media which are television, radio, newspapers and magazines to transmit and send information to a large audience. This definition shows that the messages from the media are not meant for one person but for a large diversified audience that are scattered in different places. One good thing about the messages from the media, especially the broadcast 
media is that the messages are received by the audience simultaneously.

The important roles of the media in the state earned them the title of the 'Fourth Estate of the realm' which implies that after the three arms of government (executive, legislature and the judiciary), the media are the next. The media socialise the people, get them informed of happenings around them, analyse issues of national importance to them and at the same time help to transmit the norms of values of the society from one generation to another.

A state is an organised political community under one political structure and government. According to Chandran (2008), a state is a political association of people. With these definitions, a state can be described as a set of people who are organised under a defined political structure and occupy definite territory. In the words of Johnson (2003), a state is a politically organised body of people who occupy a defined territory. Johnson adds that before a body of people can be called a state, it must have a government that drives its affairs, a defined territorial boundary, it must have the authority to control its citizens without any form of external control and its operations, power and authority must be legitimate. Examples of state are Nigeria, France, Italy, etc.

An uninformed person is in darkness; so also an uninformed society. The government of any state, in a bid to develop the state and the people cannot overlook the key roles of the various mass media we have in the society. The media are the vehicles that convey government's developmental plans and messages to the people. Libert (1972) confirms this and adds that the media as the link between the government and the governed, reporting what the government is doing directly to the citizens. As Daramola (2003) has rightly said, there is hardly any society or sovereign state that can function properly today without the mass media.

However, one cannot but mention that the media are not perfect because -they have their own shortcomings. Scholars have conducted many researches to identify the positive roles the media play in nation building.it is no gain saying that the media are very important in the society and their functions cannot be disregarded. But the mass media also perform some uncomplimentary roles that can endanger the growth of any nation. Hence, this paper examines the positive as well as the negative roles the media play in the growth and development of a nation.

\section{THEORETICAL FRAMEWORK}

The theories adopted in this study are the dependency theory and the development media theory. Melvin and Ball-Rokeach (1976) offer a view of the potentially powerful mass media, tying that power to audience members depend on. The theory assumes that audience depends on the mass media for the promotion and preservation of our cultural beliefs and values. In our modern society, people depend on the media to understand our social world and to act meaningfully in our society through proper media education.

The mass media are vehicles of social change. They reflect the changes and development that surface every day in our society. If a new product or idea springs up in our community today, it is through the media that some people would get to know about it. As the society depends on the mass media, so also the media depend on the society. The media are influenced by the cultures of the societies in which they operate. The media must therefore be conscious of the kinds of content they publish, so that the cultures of the host societies are not destroyed.

The development media theory was developed as a means of checking the imbalance in the development and flow of information in the third world countries and the solution to the technological problem facing them (Daramola, 2003). This theory was propounded by Dennis McQuail (1987). It is no gain saying that the society cannot exist nor function properly without communication because communication aids development. How will the government propagate its developmental plan to the people without the use of the mass media? That is why in this theory, the mass media partners with government to make sure things work right in the society.

The theory upholds the needs for the media to give first class priority to the national culture in their contents. The media contents should be cultural oriented and give adequate concerned about promoting societal culture, heritage and values. In view of the assertion of this theory, the mass media must act as partners to the government in ensuring the growth and development of their host societies.

Aside the other functions of the mass media, the press must work to enhance the development of the state. The theory suggests that the press and the government should work hand in hand to facilitate the development of the nation in terms of economy, political, religious, socio and other sectors of the society. The media, in this theory, works as partner to the government and not a watchdog. This is supported by Quebral (2011) as she defines the theory as "the art and science of human communication applied to the speedy transformation of a country and the mass of its people from poverty to a dynamic state of economic 
IJASOS- International E-Journal of Advances in Social Sciences, Vol. III, Issue 9, December 2017

growth that makes possible greater social equality and the larger fulfilment of the human potential."

\section{MEDIA AS FRIEND OF THE STATE}

The mass media act as friend to the state in many ways and usually a partner of the state in enhancing the development of the state. Some of these ways are discussed below:

\subsection{Media as Watchdogs}

The media are responsible for laying surveillance on the society and serve as "watch dog" to the government in order to bring news and information to the people. A watchdog press ensures that individuals and institutions who are supposed to serve the public remain transparent and are held accountable. A vigilant press, is therefore, key to good governance (Sheila, 2008)

Watchdogging covers a range of exposure journalism; it is a form of investigative journalism in which the media surveys the society, the activities of the government officials and prominent people in the society. In another way, the mass media supports the law enforcement agencies and anti-graft agencies in the country - Nigerian Police, DSS, EFCC ICPC, etc. - in bringing perpetrators of immorality, corruption and other scandals to justice.

The targets of exposés range from low-level to high-level officials or celebrities. They can be on small-scale wrongdoing involving petty officials like traffic policemen or clerks, but can just as well be on high-level political corruption involving millions or billions of naira/dollars, as in the case of Sambo Dasuki, AlisonMadueke, Patricia Eteh, Senator Bukola Saraki's false declaration of assets, among other political office holders who are involved in embezzlement scandals. Prominent among these scandals is the certificate scandal involving Salisu Buhari, the then speaker of the House of Representatives. Buhari according to what was discovered by the "The News Magazine', forged a degree certificate from the University of Toronto and lied about his age. The allegations were confirmed to be true and at the end of it all, Salisu Buhari ceased to be the Speaker of the Honourable house.

The media vehemently questioned the former Lagos state governor, Raji Fashola's N78million website scam. Fashola was said to develop the website (www.fashola.com) for his personal use with the money belonging to the state. He later explained that the sum was N12million and the upgrade of the site and its maintenance accounted for the remaining N66million. The media questioned why Fashola will develop a website with N78million. The watchdog function is performed by media in almost all the countries in the world. For instance, "Bloomberg News" exposed the money laundering scandal involving Deutsche Bank in Russia in 2016 and "Herald Sun" exposed the sex scandal in Australia, which involves Seven West Media CEO, Tim Worner in 2016. There are many more scandals and corruption cases that were exposed by the mass media.

\subsection{As Agents of Cultural Transmission}

Lasswell (1948) pointed out that the mass media transmit cultural heritage from generation to generation by communicating the norms, rules and values of the society. This is done through relay of programmes geared towards promoting the societal norms and value, dressing of the media experts to showcase the identities of the different tribes in the country. Some of these programmes are A.M Express on NTA, Goje Africa, Heritage and other programmes that focus on the promotion of societal culture and norms. The media also reports on events that promote such issues as African arts, culture and exhibition, for example - Argungun Fishing Festival that holds in Nigeria and other festivals in different parts of the continent. In addition, some dramas and soap operas teach morals. Plays like "Saworo'de", "Agogo Ewo" and epic movies promote the culture and tradition of the Yoruba society.

\subsection{Agents of Political Orientation}

Over the years, the media have become agents of political socialization through various advertorials, public service announcements, programmes and media campaigns that sensitize people in playing active roles in the governance of their countries. This role is always played more during elections. The media educate the people to register and vote for the candidates of their choices and also shun electoral violence. The media have always acted as sources of political information and education to the people and the messages from these channels are given high credibility by the people.

In addition, the media or the government, through the media, organise behavioural change campaign to sensitize the people on being good and responsible citizens in the country. 'Occupy Nigeria', Nigeria: great people, great nation, and 'Change begins with me' are some of the media campaigns that the media used to sensitize the people. The mass media are also the channels through which the government reaches out to 
the people. The plans and programmes of the government are relayed through the media.

\section{MEDIA AS ENEMY OF THE STATE}

Despite the great contributions of the mass media to the society, yet have the media played some negative roles.

\subsection{Mass Media as Attack Dogs}

Information is describes as 'power' and the way this information is controlled in the society determines the nature of affairs in that society. The mass media have been used as weapon of attack by the elite and those who have certain access and control over the media in the society. Politicians see the mass media as channels through which they attack others. Politicians throw jabs at one another via the media and these 'jabs' are at times given coverage by the media.

This was exemplified when AIT and NTA aired documentaries on retired General Muhammadu Buhari and Chief Bola TInubu during the 2015 elections campaign. AIT, on March 1st aired the documentary titled 'Lion of Bourdillon'. The documentary showcased various properties and companies across Lagos purportedly owned by Mr. Tinubu, a top leader of the APC describing him as "Nigeria's biggest landlord". It also alleged that the APC chieftain was "charged for narcotics" in 1993.

The mass media, which is saddled with the promotion of morals and virtues now serve as a battle ground for people to attack others' personalities without considering their ethical demands and social responsibilities.

\subsection{Agents of Cultural Decadence}

Despite the role of the media in promoting norms and positive behaviours that bring development to the society, the media have also contributed to decadence in the society. Musical videos and movies are laced with semi-naked people that engage in immoral acts. "Ma Roll" by Tillaman, "Go Low" by Wande Coal, "Shake" by Flavour are some of the musical videos that contain vulgar words and erotic dance. Films like "Omoge Campus", "Blackberry Babes" and the host of others contain sexually explicit scenes. Some Nigerian youths watch programmes like Big Brother Africa and Big Brother Nigeria; which allows intimacy and romance among participants who are from different parts of the country. Some internet sites supply pornography to youths.

Little wonder rape, teenage sex, prostitution, indecent dressing, violent acts, indiscipline and social vices are very high in the society. Siddhartha (2009) notes that the vulgarity displayed in the advertisements, the serials and the music videos should be checked because they reach the audience directly in their homes. The present day high-tech robbery, falling in love affairs by college and school boys and girls, opting for revealing dress by the girls are some of the perverse effects of the present day movies. These are something which the media has to guard against.

In addition, it is apparent that most of our television programmes contents are foreign oriented and this at great extent, I believe, is influencing the audience to adopt Westernised way of life in disrespect of their own culture. Uche (1986) observes the Nigerian broadcasting system and concludes that "there is a total rejection of the music of the Nigerian musician and an overwhelming preference for foreign music by Nigerian youth". Uche (1989) also adds that when we talk of endangering our local culture, we should as well be equally concerned about the structure, programme priorities, and orientation of the local electronic media establishments. The words of Uche may be true as the media give more priority to foreign contents at the expense of local ones. Little wonder why the youths of today prefer foreign clothes, shoes, musicals, books, programmes and lifestyles to the Nigerian culture.

\subsection{Promotion of Hate speeches}

Adibe (2014) states that, a "hate speech employs discriminatory epithets to insult and stigmatize others on the basis of their race, ethnicity, gender, sexual orientation or other forms of group membership. It is any speech, gesture, conduct, writing or display which could incite people to violence or prejudicial action. Hate speeches are more noticeable during elections in the country. The media feel no remorse in airing many of the hate speeches that are used on daily basis by the politicians and their supporters. There is little care to the implication theses hates speeches have on the people. Abiodun (2016) notes that hate speeches incite people into violence. Ezeibe (2015) agrees with Abiodun and posits that:

Hate speeches directed at gaining political power lead to electoral violence. Nigeria's background of intolerance provides ample grounds for the use of hate speech. Directly, it was hate 
speech and indirectly it was ethnic and religious intolerance that led to the surge in electoral violence in Nigeria from 2011 to 2015.

During the 2015 Nigerian general election campaign, Governor Fayose of Ekiti state sponsored a news paper advertorial to attack the current president (Buhari) that he would die in office just like Musa Yar'adua and Sanni Abacha died in office.

Alhaji Mujahid Dokubo-Asari said in a live programme on Channels Television that blood would flow if the then president Dr. Ebele Jonathan lost the election.

\section{CONCLUSION AND RECOMMENDATIONS}

The study concludes that the media helped in nation building by promoting political participation, culture, education and checking the activities of the government. Nevertheless, they have also promoted violence, hate speeches, immorality, propaganda and publishing more foreign contents than local contents. These negative impacts of the media can be traced to ownership influence and government interference in the media operations.

The study recommends that the media should live up to their social responsibilities and adhere to the ethics of the profession by putting honesty, truthfulness, fairness and balance up above any personal interest and also in their performance. The media should give more priority to local contents rather than the foreign ones as this will really help in promoting the culture of the nation. This will enable them to contribute more to nation building.

\section{REFERENCE LIST}

Abiodun, F. (2016). Use of Hate Speeches in Television Political Campaign: A Study Of 2015 General Election In Nigeria. A paper submitted to the Department of Mass Communication, Covenant University, Ota.

Adibe, J. (2014) Ethnicity, Hate Speech and Nation-Building: available at www.gamji.com/adibe19.htm

Akinyemi, A. (2015). The Role of Mass Media in Political Development in Nigeria. Comment on a Newspaper Report by The Nigeria Observer, published on May 21, 2015. Available at www.nigerianobservernews.com/2015/05/role-of-mass-media-in-political-development-in-nigeria.

Anyaele U. Johonson (2003). Comprehensive Government. Lagos: A. Johnson Publishers Limited.

Ball-Rokeach, J. And Defleur, M. (1976). A Dependency Model of Mass Media effects. Communication Research 3 (i). 3-21.

BBC News. Certificate forgery: The downfall of Salisu Buhari. Reported on January 24, 2015. Available at www.news.bbc.co.uk/2/hi/africa/401123.stm

Chandra , K. (2008). 'Dominations and Powers: The Nature of the State'. A paper presented at a conference at the University of Wisconsin, Madison on March 29, 2008.

Daramola, I. (2003) Introduction to Mass Communication. Lagos: Rothan Press

Daramola, I (2005) Mass media and society. Lagos: Owonike Rainbow Press Ltd.

Dominick, R.J. (1996). The Dynamics of Mass Communication. Mcgraw Hall Companies, California

Ezeibe C. (2015). Hate Speech and Electoral Violence in Nigeria. A paper submitted to the Department of Political Science University of Nigeria, Nsukka

Lasswell, H. (1948) "The Structure and Function of Communication in Society", in L. Bryson (ed.) The Communication of Ideas, pp. 32-51. New York: Harper

Liebert, R. (1972). Effects of Mass Media. Annual Review of Psychology. VOI. 28: 141-173.

McQuail, D. (1987). Mass Communication Theory: An Introduction. (2nd ed.). Berverly Hills, C.A.: SagePublications.

Quebral, N. C. (2011)Devcom los banos style. Lecture delivered during the honorary doctorate celebration seminar, LSE, University of London. 
IJASOS- International E-Journal of Advances in Social Sciences, Vol. III, Issue 9, December 2017

Segun Oruame (2015) Nigerian 2015 elections and the Internet of hate. http://itedgenews.com/2015/01/20/nigerian-2015-elections-and-the-internet-of-hate/

Sheila, C. (2008). Corruption and the watchdog role of the media.

Siddhartha D. (2009). Role Of Media In Nation Building. Available at www.odisha.gov.in/emagazine/Orissareview/2009/Jan.

The New Yorker. Deursche Bank's \$10billion Scandal. Reported on August 29, 2016. Available at www.newyorker.com/magazine/2016/08/29/deutsche-banks-10-billion-scandal

Uche, L.U. (1986), Imperialism Revisited. Media Education Journal No.6/1987 pp.30 - 33

Ukwueze, C. and Uche, A. (2015). The Rise of Hate and Peace Journalism In The Nigerian Democratization Process: The Place of the New Media. Communication Panorama African and Global Perspective. Volume 1 Number 1 Sept-Oct 2015 Maiden Issue 